\title{
PERAMALAN VOLATILITAS RETURN SAHAM MENGGUNAKAN METODE ASYMMETRIC POWER ARCH (APARCH)
}

\author{
Juita Haryati Sidadolog $^{1 \S}$, I Wayan Sumarjaya ${ }^{2}$, Ni Ketut Tari Tastrawati ${ }^{3}$ \\ ${ }^{1}$ Program Studi Matematika, Fakultas MIPA - Universitas Udayana [Email: juitapurba.jp@gmail.com] \\ ${ }^{2}$ Program Studi Matematika, Fakultas MIPA - Universitas Udayana [Email: sumarjaya@unud.ac.id] \\ ${ }^{3}$ Program Studi Matematika, Fakultas MIPA - Universitas Udayana [Email: tastrawati@unud.ac.id] \\ ${ }^{\S}$ Corresponding Author
}

\begin{abstract}
Model APARCH is one of the asymmetric GARCH models. These models are able to capture the incidence of good news and bad news in the volatility. The APARCH model has an asymmetric coefficient to cope with leverage effect by modeling a leverage that has heteroscedasticity and asymmetric effect condition. The results of this research were obtained by the appropriate APARCH model. The model is the APARCH(1,2) model because all parameters are significant. Thus, proceeds from the volatility of stock return for the next 14 days with the model volatility APARCH $(1,2)$ increased from period one to period fourteen.
\end{abstract}

Keywords: APARCH, volatility, asymmetric.

\section{PENDAHULUAN}

Pasar modal dalam perekonomian dunia semakin berkembang. Di pasar modal inilah investor dapat memilih berbagai investasi. Kegiatan-kegiatan yang terjadi pada pasar modal akan membentuk suatu deret data yang sering disebut dengan data deret waktu. Data deret waktu memuat sekumpulan informasi berdasarkan periode waktu tertentu.

Data deret waktu pada bidang finansial umumnya memiliki volatilitas yang tidak konstan sehingga varians akan selalu berubah atau heterogen. Hal tersebut menyebabkan ketidakpastian sehingga para investor harus lebih berhati-hati dalam melakukan kegiatan investasi. Di lain pihak, maraknya perkembangan harga saham di pasar modal telah mendorong banyaknya calon investor untuk lebih mengetahui saham-saham yang prospektif untuk dibeli baik saat ini maupun beberapa periode ke depan. Untuk ketidakpastian tersebut di atas, maka perlu dilakukan peramalan volatilitas pada return saham. Peramalan volatilitas sangat penting dalam bidang finansial karena akan memberikan dasar yang lebih baik bagi perencanaan dan pengambilan keputusan. Oleh karena itu, peneliti telah mengembangkan beberapa model pendekatan untuk mengukur volatilitas.
Pada tahun 1982, Engle memperkenalkan model autoregressive conditional heteroscedasticity (ARCH). Kemudian model ARCH tersebut dikembangkan lebih lanjut oleh Bollersev pada tahun 1986 menjadi model GARCH (generalized autoregressive conditional heteroscedasticity). Model ARCH dan GARCH memiliki respon yang simetris terhadap guncangan positif (good news) maupun guncangan negative (bad news). Namun, dalam beberapa kasus terdapat perbedaan besarnya perubahan pada volatilitas ketika terjadi pergerakan nilai return, yang disebut dengan pengaruh keasimetrikan.

Menurut Tsay (2002), kelemahan model ARCH/GARCH tersebut bisa diperbaiki dengan menggunakan model GARCH asimetris. Salah satu model GARCH asimetris adalah model asymmetric power $\mathrm{ARCH}$ (APARCH). Model APARCH adalah model yang mampu menangkap kejadian ketidakasimetrisan good news dan bad news dalam volatilitas dengan menyatakan koefisien asymmetric untuk mengatasi leverage effect dalam perhitungan.

Penelitian sebelumnya terkait dengan peramalan volatilitas return saham dilakukan oleh Elvitra (2013). Penelitian tersebut meramalkan volatilitas pada return nilai tukar 
rupiah terhadap dolar dengan menggunakan model volatilitas APARCH. Pada hasil penelitian diketahui bahwa model $\operatorname{APARCH}(1,3)$ mengalami peningkatan dan pergerakan untuk peramalan rata-rata pada return nilai tukar rupiah terhadap dolar untuk 18 periode selanjutnya adalah konstan.

Berdasarkan penelitian tersebut dan pemaparan yang telah diuraikan, maka dalam penelitian ini dilakukan peramalan volatilitas return data harian harga penutupan saham PT Perusahaan Gas Negara (Persero) Tbk.

\section{METODE PENELITIAN}

Data yang digunakan dalam penelitian ini adalah data sekunder yaitu data harian harga penutupan (closing price) PT Perusahaan Gas Negara (Persero) Tbk. pada periode 17 Januari 2011 sampai dengan 16 Agustus 2019.

Adapun metode analisis yang digunakan pada penilitian tugas akhir ini diuraikan sebagai berikut:

1. Melakukan plot data return penutupan harga saham PT Perusahaan Gas Negara (Persero) Tbk.

2. Menghitung nilai stylised fact untuk mengetahui apakah data berdistribusi normal.

3. Melakukan pengujian efek ARCH dengan:

a. melihat fungsi autokorelasi,

b. menggunakan uji ARCH-LM.
4. Mengidentifikasi model GARCH untuk mengatasi heteroskedastisitasnya.

5. Kemudian dilakukan estimasi parameter model GARCH dan dilakukan evaluasi untuk memilih model GARCH terbaik dengan kriteria AIC terkecil.

6. Melakukan pengujian efek asimetris pada model GARCH. Pengujian dilakukan dengan uji sign bias test.

a. Jika volatilitas data bersifat simetris, maka tetap menggunakan model GARCH;

b. Jika volatilitas data bersifat asimetris, maka menggunakan model APARCH.

7. Membentuk model volatilitas APARCH.

8. Mengestimasi parameter model volatilitas APARCH.

9. Melakukan verifikasi model volatilitas APARCH dengan melakukan uji berdasarkan nilai AIC terkecil.

10. Melakukan forecasting (prediksi) volatilitas return penutupan harga saham PT Perusahaan Gas Negara (Persero) Tbk. dengan model APARCH untuk beberapa periode ke depan.

\section{HASIL DAN PEMBAHASAN}

\subsection{Analisi Deskriptif}

Pada tahap ini dilakukan plot data harga penutupan (closing price) harian harga saham PT Perusahaan Gas Negara (Persero) Tbk. (PGAS) dalam rupiah dengan data amatan sebanyak 2133 data. Plot data harga penutupan (closing price) saham PT Perusahaan Gas Negara (Persero) Tbk. (PGAS) dapat dilihat pada Gambar 1.

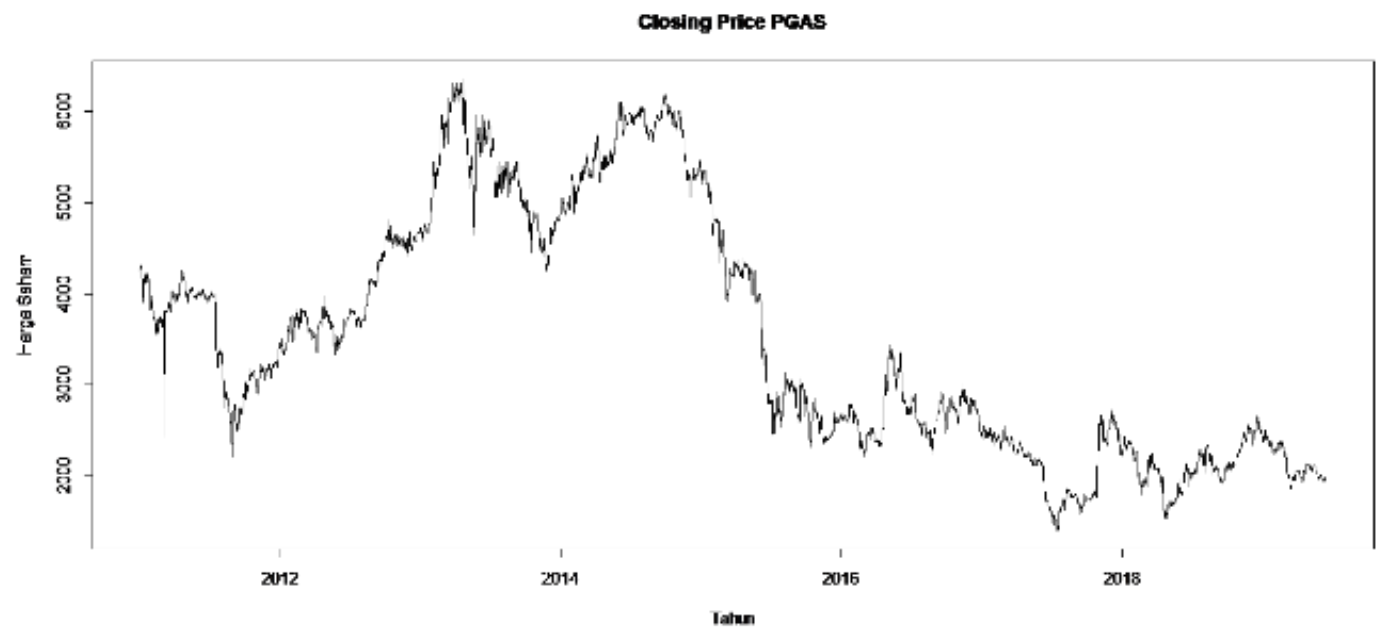

Gambar 1. Plot Closing Price Saham PGAS 
Berdasarkan Gambar 1 dapat dilihat bahwa pergerakan harga penutupan (closing price) harian saham harian PGAS berfluktuasi dari waktu ke waktu. Penurunan harga penutupan harian (closing price) PGAS yang sangat tajam terjadi pada awal tahun 2011. Penurunan ini disebabkan karena pemerintah menurunkan harga gas untuk industri dalam rangka meningkatkan kinerja industri di tengah perlambatan ekonomi.

Plot harga penutupan (closing price) harian saham harian PGAS juga dapat digunakan untuk melihat kestasioneran dengan melihat apakah plot memiliki tren naik, tren turun, musiman dan siklus. Berdasarkan Gambar 1 diketahui bahwa setelah terjadi penurunan yang tajam pada awal tahun 2011, pada periode pertengahan 2011 hingga pertengahan tahun 2013 saham mengalami peningkatan secara berangsur-angsur. Pola tren naik ini diikuti dengan tren turun sampai pada periode akhir tahun 2013. Karena terdapat tren naik dan tren turun pada harga penutupan (closing price) saham PGAS, data tersebut tidak stasioner. Oleh karena itu, akan dilakukan proses differencing terhadap data dengan mencari return.

\subsection{Return}

Berdasarkan data saham PGAS yang diperoleh, data saham pertama adalah 4.250 dan data saham kedua adalah 4.275. Sehingga, nilai return periode pertama adalah:

$$
r_{t}=\ln \frac{4.275}{4.250}=0,005865119 .
$$

Cara yang sama dapat dilakukan untuk menghitung nilai $r_{t}$ berikutnya dengan $t=1,2, \ldots, 2.133$. Return yang diperoleh sebanyak 2.132. Berikut ini plot data return pada Gambar 2.

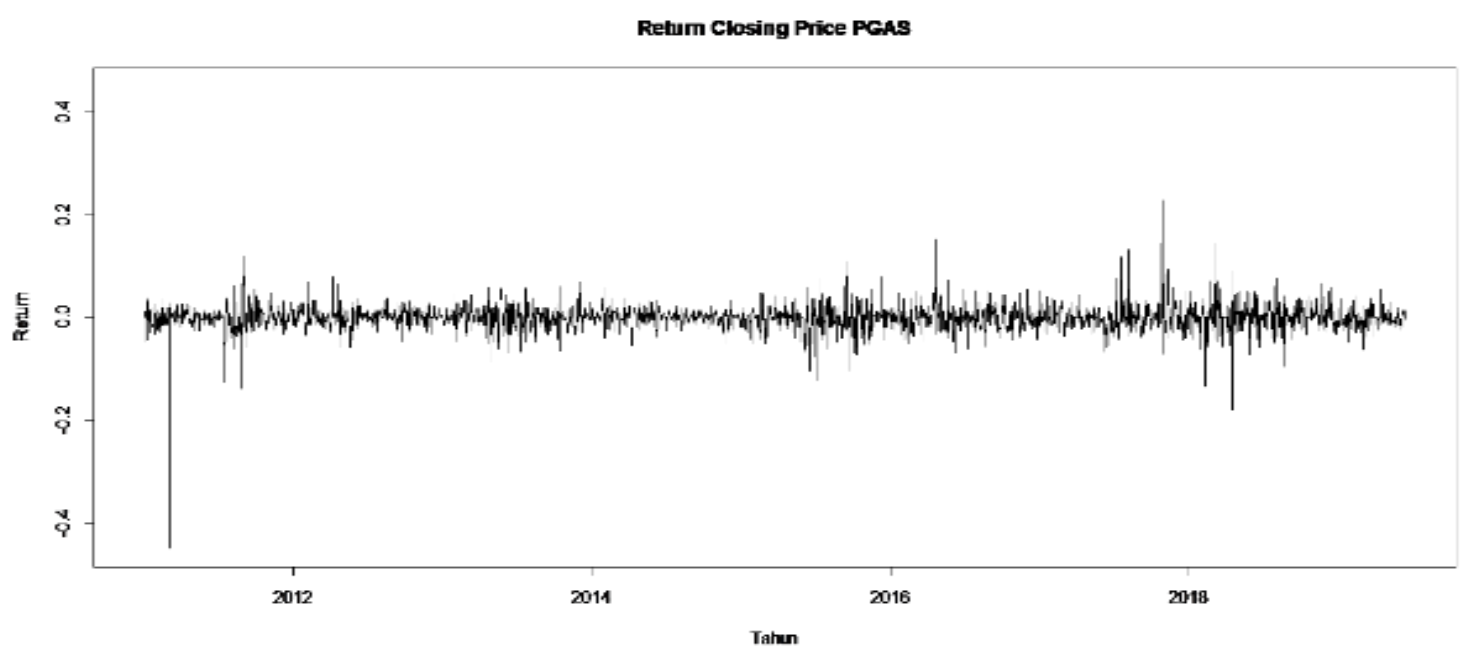

Gambar 2. Plot Return Closing Price PGAS

Berdasarkan Gambar 2 dapat dilihat bahwa pada tahun 2011 pergerakan return cenderung lebih fluktuatif dibanding tahun-tahun yang lainnya karena pemerintah menurunkan harga gas untuk industri pada periode tersebut. Peristiwa ini mengindikasikan adanya volatility clustering yaitu kondisi pergerakan data deret waktu cenderung naik atau turun secara drastis dan tiba-tiba dalam suatu kondisi tertentu.

\subsection{Deskriptif Data}

Analisis karakteristik data return saham PGAS menggunakan statistik deskriptif. Deskriptif data return saham PGAS dapat dilihat pada Tabel 1.
Tabel 1. Deskriptif Data Return Sahan PGAS

\begin{tabular}{|c|c|}
\hline Statistik Deskriptif & Nilai \\
\hline Banyak data & 2.132 \\
\hline Skewness & 0,251792 \\
\hline Kurtosis & 58,382450 \\
\hline
\end{tabular}

Sumber: Data diolah (2020)

Distribusi normal memiliki nilai skewness nol dan nilai kurtosis tiga sehingga excess kurtosis atau kurtosis berlebih $(K-3)$ adalah nol. Berdasarkan statistik deskriptif pada Tabel 1 , return dari saham PGAS memiliki nilai skewness yang positif. Nilai skewness yang positif menunjukkan bahwa distribusi dari return saham PGAS memiliki ekor kanan yang 
lebih panjang daripada ekor kiri sehingga menggambarkan ketidakasimetrisan data atau data tidak berdistribusi normal. Kemudian return saham PGAS memiliki nilai kurtosis yang lebih dari tiga. Sehingga diperoleh kurtosis berlebih (excess kurtosis) sebesar 55,382450 mengindikasikan data return saham tidak berdistribusi normal. Gambar 3 menunjukkan bentuk histogram meruncing dan tidak simetris yang mengindikasikan bahwa return saham PGAS tidak berdistribusi normal.

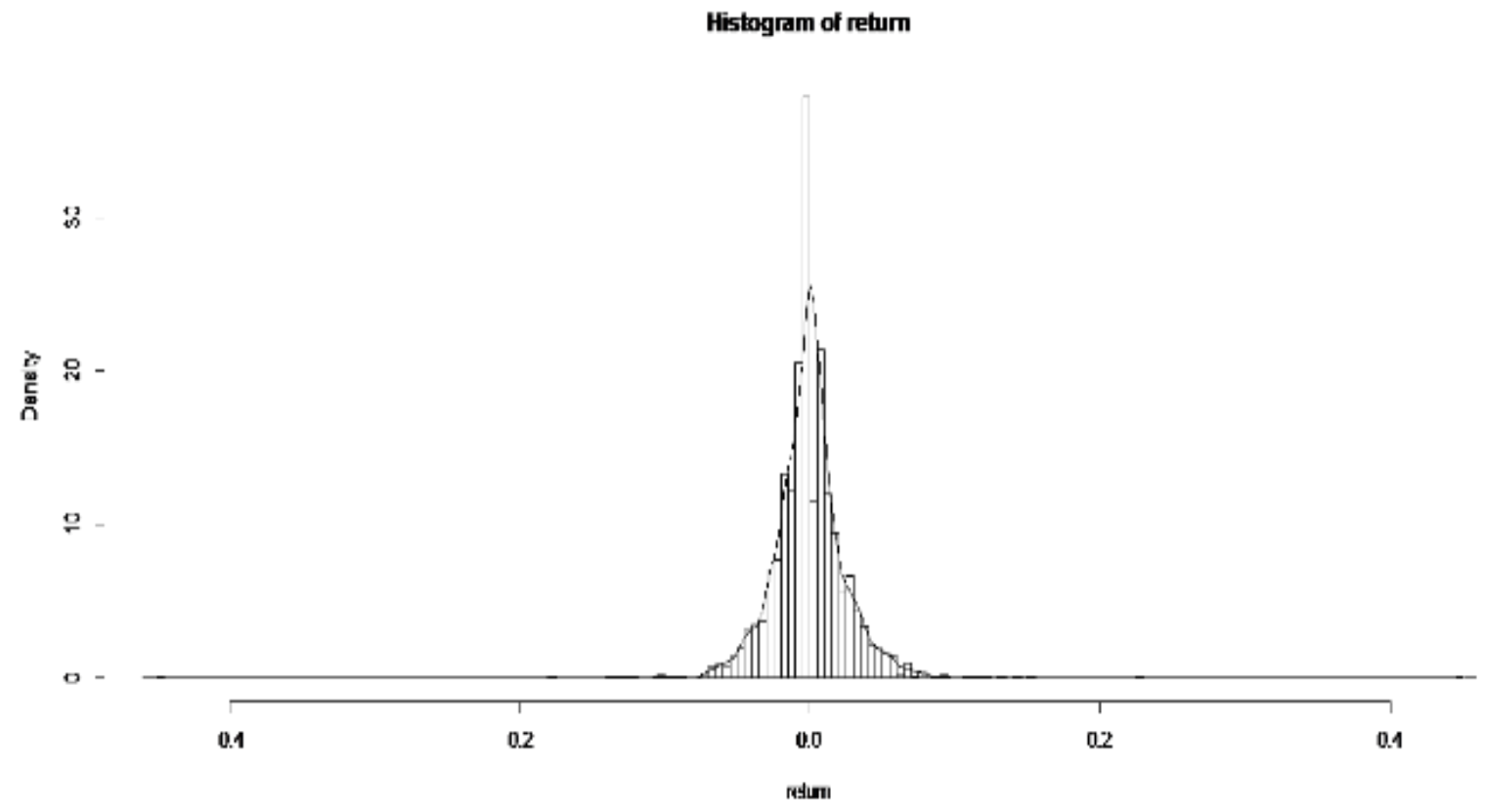

Gambar 3. Histogram Return Closing Price Saham PGAS

\subsection{Pemeriksaan Kestasioneran}

Identifikasi stasioneritas pada return saham dapat dilakukan dengan melihat tampilan grafik korelogram nilai fungsi autokorelasi (ACF) dan

ACF Retum PGAS

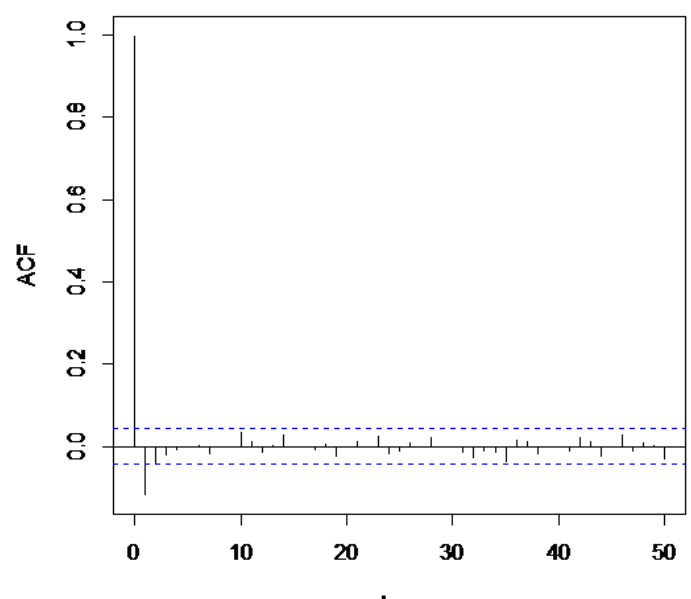

fungsi autokorelasi parsial (PACF) serta uji Augmented Dickey Fuller (ADF). Tampilan grafik ACF dan PACF dapat dilihat pada Gambar 4.

Gag 
Berdasarkan Gambar 4 dapat terlihat bahwa hanya beberapa lag yang keluar dari garis Bartlet. Oleh karena itu, data return saham stasioner. Selanjutnya akan dilakukan pemeriksaan kestasioneran dengan uji Augmented Dickey Fuller (ADF). Statistik uji yang digunakan pada uji ADF yaitu statistik uji-t. Hipotesis yang digunakan adalah:

$H_{0}: \beta=0$ (terdapat unit root atau data tidak stasioner).

$H_{1}: \beta \neq 0$ (tidak terdapat unit root atau data stasioner).

Kriteria keputusan yang digunakan adalah tolak $H_{0}$ jika $p$-value $<\alpha$ (Tsay, 2013).

Nilai statistik $t$ yang diperoleh adalah sebesar -12,814 dan $p$-value sebesar 0,01 dengan taraf uji $\alpha=0,05$. Karena $p$-value $=$ 0,01 lebih kecil dari $\alpha=0,05$, sehingga cukup bukti untuk menolak hipotesis nol. Hal ini berarti data return saham tidak terdapat unit root atau data stasioner. Karena data return saham PGAS terbukti stasioner, selanjutnya akan diuji apakah terdapat korelasi dan heteroskedastisitas pada data return.

\subsection{Uji Korelasi dan Uji Heteroskedastisitas}

Keberadaan efek korelasi dan heteroskedastisitas dapat diketahui dengan melakukan uji Ljung-Box dan uji ARCH-LM (Lagrange Multiplier) pada residual kuadrat dari return. Hipotesis yang digunakan untuk mendeteksi efek korelasi dengan menggunakan uji Ljung-Box adalah:

$H_{0}: \rho_{1}=\rho_{2}=\cdots=\rho_{i}=0$ (data tidak

berkorelasi);

Tabel 2. Estimasi Parameter Model GARCH

\begin{tabular}{|l|c|c|c|c|}
\hline \multicolumn{1}{|c|}{ Model } & Parameter & Estimasi Parameter & $\begin{array}{c}t- \\
\text { statistic }\end{array}$ & $p$-value \\
\hline GARCH & $\alpha_{0}$ & $1,881 \times 10^{-4}$ & 4,997 & 0 \\
$(1,1)$ & $\alpha_{1}$ & $2,730 \times 10^{-1}$ & 6,627 & 0 \\
\hline & $\beta_{1}$ & $5,380 \times 10^{-1}$ & 8,364 & 0 \\
\hline \multirow{G}{*}{ GARCH } & $\alpha_{0}$ & $1,872 \times 10^{-4}$ & 4,312 & $1,62 \times 10^{-5}$ \\
$(1,2)$ & $\alpha_{1}$ & $2,724 \times 10^{-1}$ & 5,935 & 0 \\
& $\beta_{1}$ & $5,396 \times 10^{-1}$ & 5,865 & 0 \\
\hline \multirow{3}{*}{ GARCH } & $\beta_{2}$ & $1 \times 10^{-8}$ & 0,000 & 0 \\
$(2,1)$ & $\alpha_{0}$ & $4,209 \times 10^{-4}$ & 17,932 & 0 \\
& $\alpha_{1}$ & $2,291 \times 10^{-1}$ & 6,550 & 0 \\
GARCH & $\alpha_{2}$ & $3,880 \times 10^{-1}$ & 7,013 & 0 \\
$(2,2)$ & $\beta_{1}$ & $N A$ & $N A$ & 0 \\
& $\alpha_{0}$ & $3,514 \times 10^{-4}$ & 8,158 & 0 \\
& $\alpha_{1}$ & $2,186 \times 10^{-1}$ & 6,416 & 1 \\
& $\alpha_{2}$ & $4,000 \times 10^{-1}$ & 7,076 & 0,0636 \\
\hline
\end{tabular}

Sumber: Data diolah (2020)
$H_{1}: \rho_{i} \neq 0, i=1,2, \ldots, k$ (data berkorelasi).

Diperoleh $p$-value lebih kecil dari $2,2 \times$ $10^{-16}$ dengan taraf uji $\alpha=0,05$. Karena $p$-value $=0,01$ lebih kecil dari $\alpha=0,05$, sehingga cukup bukti untuk menolak hipotesis nol. Hal ini berarti terdapat korelasi pada residual kuadrat data return saham.

Kemudian selanjutnya adalah mendeteksi keberadaan heteroskedastisitas pada data return saham dengan menggunakan uji ARCH-LM. Hipotesis yang digunakan adalah:

$H_{0}: \alpha_{1}=\alpha_{2}=\cdots=\alpha_{p}=0$ (tidak terdapat efek ARCH);

$H_{1}$ : Paling tidak ada satu $\alpha_{i} \neq 0, i=1,2, \ldots, p$ (ada pengaruh efek ARCH).

Diperoleh $p$-value lebih kecil dari 2,2 $\times$ $10^{-16}$ dengan taraf uji $\alpha=0,05$. Karena $p$ - value $=0,01$ lebih kecil dari $\alpha=0,05$, sehingga keputusannya adalah tolak hipotesis nol. Hal ini berarti terdapat efek ARCH atau heteroskedastisitas pada data return closing price saham. Setelah diketahui bahwa data return closing price saham PGAS memiliki efek ARCH, kemudian dimodelkan ke dalam bentuk GARCH

\subsection{Estimasi Parameter Model GARCH}

Berikut ini adalah hasil estimasi untuk masing-masing parameter model GARCH yang ditampilkan pada Tabel 2. 
Model GARCH yang dipilih untuk meramalkan data adalah model dengan nilai AIC terkecil. Nilai AIC untuk model GARCH(1,1) adalah:

$$
\begin{aligned}
\text { AIC } & =-2\left(\frac{4729,773}{2132}\right)+2\left(\frac{4}{2132}\right) \\
& =-4,43693527+0,003752 \\
& =-4,433183 .
\end{aligned}
$$

Nilai AIC untuk model GARCH(1,2) adalah:

$$
\begin{aligned}
\text { AIC } & =-2\left(\frac{4729,753}{2132}\right)+2\left(\frac{5}{2132}\right) \\
& =-4,43691651+0,0046904 \\
& =-4,43222611 .
\end{aligned}
$$

Nilai AIC untuk model GARCH(2,1) adalah:

$$
\begin{aligned}
A I C & =-2\left(\frac{4745,584}{2132}\right)+2\left(\frac{5}{2132}\right) \\
& =-4,45176735+0,0046904 \\
& =-4,44707695 .
\end{aligned}
$$

Nilai AIC untuk model GARCH(2,2) adalah:

$$
\begin{aligned}
A I C & =-2\left(\frac{4748,185}{2132}\right)+2\left(\frac{6}{2132}\right) \\
& =-4,4420732+0,0056285 \\
& =-4,43651035 .
\end{aligned}
$$

Berdasarkan nilai AIC yang diperoleh, nilai AIC yang terkecil adalah model $\operatorname{GARCH}(2,1)$. Namun, pada model $\operatorname{GARCH}(2,1)$ terdapat satu parameter yang tidak signifikan pada tingkat signifikansi 5\%. Oleh karena itu, model GARCH yang sesuai adalah model $\operatorname{GARCH}(1,1)$ karena semua paramternya signifikan dengan persamaan sebagai berikut:

$$
\begin{aligned}
\sigma_{t}^{2}= & \alpha_{0}+\alpha_{1} \varepsilon_{t-1}^{2}+\beta_{1} \sigma_{t-1}^{2} \\
= & 1,881 \times 10^{-4}+2,730 \times 10^{-1} \varepsilon_{t-1}^{2} \\
& +5,380 \times 10^{-1} \sigma_{t-1}^{2}
\end{aligned}
$$

\subsection{Uji Sign Bias Test}

Sign bias test digunakan untuk melihat apakah terdapat efek asimetris ataau tidak pada data. Untuk memerisa pengaruh efek asimetris, data deret waktu dimodelkan ke dalam model GARCH kemudian pengujian efek asimetris terhadap residual. Statistik uji yang digunakan adalah statistik uji $F$. Hipotesis yang diuji adalah:

$H_{0}: \varphi_{0}=\varphi_{1}=\varphi_{2}=\varphi_{3}=0$ (residual bersifat simetris);

$H_{1}$ : Paling tidak ada satu $\varphi_{i} \neq 0, i=0,1,2,3$ (residual bersifat asimetris).

Berikut ini adalah hasil dari uji sign bias test pada model GARCH $(1,1)$.

Tabel 3. Hasil Uji Sign Bias Test

\begin{tabular}{|l|c|c|c|}
\hline & $\begin{array}{c}t- \\
\text { statistic }\end{array}$ & $\begin{array}{c}p- \\
\text { value }\end{array}$ & Significant \\
\hline Sign Bias & 1,369333 & 0,171039675 & \\
\hline Negative Sign Bias & 3,062249 & 0,002224308 & $* * *$ \\
\hline Positive Sign Bias & 0,676236 & 0,498964168 & \\
\hline Joint Effect & 9,834669 & 0,020025076 & $* *$ \\
\hline
\end{tabular}

Sumber: Data diolah (2020)

Parameter sign bias, negative sign bias dan positive sign bias adalah faktor-faktor yang menyiratkan dampak besarnya guncangan positif atau negatif pada volatilitas yang diprediksi. Joint Effect merupakan efek gabungan dari sign bias, negative size bias, dan positive size bias. Semakin banyak bintang yang diperoleh, semakin signifikan parameternya. Jika salah satu koefisien pada parameter tersebut signifikan, maka residual dari model $\operatorname{GARCH}(1,1)$ bersifat asimetris. Berdasarkan Tabel 3 diperoleh bahwa terdapat dua parameter yang signifikan, sehingga kriteria keputusannya tolak hipotesis nol. Hal ini berarti, terdapat efek asimetris pada model $\operatorname{GARCH}(1,1)$. Selanjutnya model $\operatorname{GARCH}(1,1)$ akan dimodelkan ke model APARCH.

\subsection{Estimasi Parameter Model APARCH}

Setelah diketahui bahwa $\operatorname{GARCH}(1,1)$ memiliki efek asimetris, selanjutnya akan dimodelkan ke model APARCH. Berikut ini adalah hasil estimasi untuk masing-masing parameter model APARCH pada Tabel 4. 
Tabel 4. Estimasi Parameter Model APARCH

\begin{tabular}{|c|c|c|c|c|}
\hline Model & Parameter & Estimasi Parameter & $\begin{array}{c}t- \\
\text { statistic }\end{array}$ & $p$-value \\
\hline $\begin{array}{c}\text { APARCH } \\
(1,1)\end{array}$ & $\begin{array}{c}\omega \\
\alpha_{1} \\
\gamma_{1} \\
\beta_{1} \\
\delta\end{array}$ & $\begin{array}{c}0,004819 \\
0,216773 \\
-0,038857 \\
0,699975 \\
0,967684\end{array}$ & $\begin{array}{c}3,477 \\
7,055 \\
-0,592 \\
11,337 \\
9,901\end{array}$ & $\begin{array}{c}0,000507 \\
0 \\
0,554086 \\
0 \\
0 \\
\end{array}$ \\
\hline $\begin{array}{c}\text { APARCH } \\
(1,2)\end{array}$ & $\begin{array}{l}\omega \\
\alpha_{1} \\
\gamma_{1} \\
\beta_{1} \\
\beta_{2} \\
\delta \\
\end{array}$ & $\begin{array}{c}0 ., 0008554 \\
0,0715341 \\
0,8076653 \\
0,3424767 \\
0,6009069 \\
0,7224818 \\
\end{array}$ & $\begin{array}{l}3,097 \\
6,850 \\
6,011 \\
4,440 \\
7,799 \\
9,173 \\
\end{array}$ & $\begin{array}{c}0,00195 \\
0 \\
0 \\
0 \\
0 \\
0 \\
\end{array}$ \\
\hline $\begin{array}{c}\text { APARCH } \\
(2,1)\end{array}$ & $\begin{array}{l}\omega \\
\alpha_{1} \\
\alpha_{2} \\
\gamma_{1} \\
\gamma_{2} \\
\beta_{1} \\
\delta\end{array}$ & $\begin{array}{c}4,962 \times 10^{-3} \\
2,484 \times 10^{-1} \\
3,002 \times 10^{-1} \\
1,191 \times 10^{-1} \\
-2,537 \times 10^{-1} \\
1 \times 10^{-8} \\
1,344\end{array}$ & $\begin{array}{c}17,171 \\
8,386 \\
7,857 \\
1,594 \\
-3,253 \\
N A \\
8,087 \\
\end{array}$ & $\begin{array}{c}0 \\
0 \\
0 \\
0,11102 \\
0,00114 \\
N A \\
0 \\
\end{array}$ \\
\hline $\begin{array}{c}\text { APARCH } \\
(2,2)\end{array}$ & $\begin{array}{l}\omega \\
\alpha_{1} \\
\alpha_{2} \\
\gamma_{1} \\
\gamma_{2} \\
\beta_{1} \\
\beta_{2} \\
\delta \\
\end{array}$ & $\begin{array}{c}3,268 \times 10^{-3} \\
2,356 \times 10^{-1} \\
3,133 \times 10^{-1} \\
1,382 \times 10^{-1} \\
-2,609 \times 10^{-1} \\
1 \times 10^{-8} \\
1,430 \times 10^{-1} \\
1,389 \\
\end{array}$ & $\begin{array}{c}3,729 \\
7,248 \\
3,111 \\
1,778 \\
-2,907 \\
0,000 \\
2,094 \\
4,359 \\
\end{array}$ & $\begin{array}{c}0,000192 \\
0 \\
0,001863 \\
0,075392 \\
0,003652 \\
1,000000 \\
0,036282 \\
1,31 \times 10^{-5} \\
\end{array}$ \\
\hline
\end{tabular}

Sumber: Data diolah (2020)

Pemilihan model APARCH yang terbaik juga dapat dilakukan dengan menggunakan kriteria AIC. Nilai AIC untuk model APARCH $(1,1)$ adalah:

$$
\begin{aligned}
A I C & =-2\left(\frac{4745,994}{2132}\right)+2\left(\frac{5}{2132}\right) \\
& =-4,45215197+0,0046904 \\
& =-4,44746157 .
\end{aligned}
$$

Nilai AIC untuk model APARCH(1,2) adalah:

$$
\begin{aligned}
A I C & =-2\left(\frac{-3070,565}{2132}\right)+2\left(\frac{6}{2132}\right) \\
& =2,88045497+0,0056285 \\
& =2,88608349 .
\end{aligned}
$$

Nilai AIC untuk model APARCH(2,1) adalah:

$$
\begin{aligned}
A I C & =-2\left(\frac{4755,985}{2132}\right)+2\left(\frac{7}{2132}\right) \\
& =-4,46152439+0,0065666 \\
& =-4,45495779 .
\end{aligned}
$$

Nilai AIC untuk model APARCH(2,2) adalah:

$$
\begin{aligned}
\text { AIC } & =-2\left(\frac{4759,556}{2132}\right)+2\left(\frac{8}{2132}\right) \\
& =-4,4648743+0,0075046 \\
& =-4,4573697 .
\end{aligned}
$$

Cara mengungkapkan pemilihan model yang terbaik tidak cukup hanya melihat nilai AIC yang perbedaannya tidak signifikan (perseratusan/ dalam 2 desimal), diperhatikan juga signifikansi parameternya. Berdasarkan nilai AIC yang diperoleh, nilai AIC yang terkecil adalah model $\operatorname{APARCH}(2,2)$. Namun, pada model $\operatorname{APARCH}(2,2)$ terdapat dua parameter yang tidak signifikan pada tingkat signifikansi $5 \%$. Oleh karena itu, model APARCH yang sesuai adalah model APARCH $(1,2)$ karena semua parameternya signifikan dengan persamaan sebagai berikut:

$$
\begin{aligned}
\sigma_{t}^{\delta}= & \omega+\sum_{j=1}^{q} \alpha_{j}\left(\left|\varepsilon_{t-j}\right|-\gamma_{j} \varepsilon_{t-j}\right)^{\delta}+\sum_{i=1}^{p} \beta_{i}\left(\sigma_{t-i}\right)^{\delta} \\
= & 0,0008554+0,0715341\left(\left|\varepsilon_{t-1}\right|-0,8076653 \varepsilon_{t-1}\right)^{0,7224818}+ \\
& 0,3424767\left(\sigma_{t-1}\right)^{0,7224818}+0,6009069\left(\sigma_{t-2}\right)^{0,7224818}
\end{aligned}
$$


$\omega$ merupakan parameter $\mathrm{ARCH}$ dengan nilai 0,0008554 . Nilai koefisien $\alpha_{1}$ yang bernilai positif yaitu 0,0715341 yang berarti bahwa guncangan negatif ( $b a d$ news) yang terjadi pada periode sebelumnya $(t-1)$ memiliki efek yang lebih besar pada varian saat ini $(t)$. Kemudian karena $\gamma_{1} \neq 0$, terdapat efek asimetris pada suatu pasar saham, artinya terdapat perbedaan pengaruh antara bad news ataupun good news terhadap volatilitas return suatu saham saat ini (Sari, 2017).

Selanjutnya, nilai koefisien $\beta_{1}$ dan $\beta_{2}$ adalah parameter dari model GARCH bernilai positif dan signifikan, yang berarti bahwa volatilitas pada saat ini tergantung dari volatilitas beberapa periode sebelumnya. Parameter $\delta$ memperlihatkan efek asimetris pada volatilitas return saham.

\subsection{Peramalan Volatilitas}

Data PT Perusahaan Gas Negara (Persero) Tbk. akan diramalkan untuk empat belas hari ke depan. Hasil peramalan volatilitas return saham S\&P 500 dapat dilihat pada Tabel 5.

Tabel 5. Hasil Peramalan Volatilitas Return Saham PGAS

\begin{tabular}{|c|c|c|}
\hline Indeks & Hari ke- & Hasil Peramalan \\
\hline 1 & 2.134 & 0,006719130 \\
\hline 2 & 2.135 & 0,006840933 \\
\hline 3 & 2.136 & 0,006959800 \\
\hline 4 & 2.137 & 0,007075802 \\
\hline 5 & 2.138 & 0,007189004 \\
\hline 6 & 2.139 & 0,007299473 \\
\hline 7 & 2.140 & 0,007407274 \\
\hline 8 & 2.141 & 0,007512469 \\
\hline 9 & 2.142 & 0,007615121 \\
\hline 10 & 2.143 & 0,007715288 \\
\hline 11 & 2.144 & 0,007813031 \\
\hline 12 & 2.145 & 0,007908407 \\
\hline 13 & 2.146 & 0,008001473 \\
\hline 14 & 2.147 & 0,008092283 \\
\hline
\end{tabular}

Sumber: Data diolah (2020)

Hasil peramalan yang tepat akan lebih baik apabila dilakukan peramalan dalam jangka waktu yang pendek yaitu selama empat belas hari ke depan karena data finansial sering mengalami perubahan setiap detiknya. Berdasarkan Tabel 5, hasil peramalan volatilitas return saham PT Perusahaan Gas Negara (Persero) Tbk. dengan menggunakan APARCH $(1,2)$ mengalami peningkatan hingga periode ke empat belas.

\section{KESIMPULAN DAN SARAN}

Setelah dilakukan analisis terhadap data return indeks harga saham PT Perusahaan Gas Negara (Persero) Tbk. periode 17 Januari 2011 sampai dengan 16 Agustus 2019 diperoleh model terbaik adalah model $\operatorname{APARCH}(1,2)$ dengan persamaan:

$$
\begin{aligned}
\sigma_{t}^{\delta}= & 0,0008554+0,0715341\left(\left|\varepsilon_{t-1}\right|+\right. \\
& \left.0,8076653 \varepsilon_{t-1}\right)^{0,7224818}+ \\
& 0,3424767\left(\sigma_{t-1}\right)^{0,7224818}+ \\
& 0,6009069\left(\sigma_{t-2}\right)^{0,7224818}
\end{aligned}
$$

Hasil dari peramalan volatilitas return saham PT Perusahaan Gas Negara (Persero) Tbk. untuk empat belas hari ke depan dengan menggunakan model volatilitas $\operatorname{APARCH}(1,2)$ mengalami peningkatan dari periode pertama sampai dengan periode ke empat belas.

Untuk penelitian selanjutnya, disarankan untuk menggunakan model lain yang memiliki karakteristik yang sama yakni m odel IGARCH (Integrated GARCH) dan CGARCH (Component GARCH).

\section{DAFTAR PUSTAKA}

Bollerslev, $\quad$ T., $\quad$ 1986. Generalized Autoregressive Conditional Heteroscedasticity. Journal of Econometrics, 31(3), pp. 307-327.

Elvitra, C. W., 2013. Metode Peramalan Menggunakan Model Volatilitas Asymmetric Power Autoregressive Conditional Heteroscedaxticity Pada Return Nilai Tukar Rupiah Terhadap Dollar. Prosiding Seminar Nasional Statistika Universitas Diponegoro 2013 , p. 488.

Engle, R. F., 1982. Autoregressive Conditional Heteroscedasticity with Estimates of The Variance of United. Econometrica, 50(4), pp. 987-1007.

Tsay, R. S., 2002. Analysis of Financial Time Series Financial Econometrics. New Jersey : John Wiley \& Sons.

Tsay, R. S., 2013. Multivariate Time Series Analysis: with $R$ and Financial Applications. New Jersey: John Wiley \& Sons. 